CLINICAL STUDY

\title{
Association between hepatic steatosis and serum IGF1 and IGFBP-3 levels in a population-based sample
}

\author{
Henry Völzke ${ }^{1}$, Matthias Nauck $^{2}$, Rainer Rettig ${ }^{3}$, Marcus Dörr ${ }^{4}$, Claire Higham ${ }^{5}$, Georg Brabant ${ }^{5}$ \\ and Henri Wallaschofski ${ }^{2}$ \\ ${ }^{1}$ Institute of Community Medicine, ${ }^{2}$ Institute of Clinical Chemistry and Laboratory Medicine, ${ }^{3}$ Institute of Physiology and ${ }^{4}$ Department of Internal \\ Medicine B, University of Greifswald, Greifswald D-17487, Germany and ${ }^{5}$ Department of Endocrinology, Christie Hospital, University of Manchester, \\ Manchester, M2O 4BX, UK \\ (Correspondence should be addressed to H Völzke who is now at Institute for Community Medicine, Ernst Moritz Arndt University, Walther Rathenau \\ Street 48,D-17487 Greifswald, Germany; Email: voelzke@uni-greifswald.de)
}

\begin{abstract}
Context: It is assumed that hepatic steatosis plays a role in the development and progression of the metabolic syndrome and its cardiovascular sequelae. Low serum IGF1 levels might mediate these associations.

Objectives: The aims of this study were i) to investigate the associations of hepatic steatosis with serum IGF1 and IGF binding protein-3 (IGFBP-3) levels using ultrasound and serum alanine aminotransaminase (ALT) data to define hepatic steatosis, and ii) to analyze the specific role of alcohol consumption in this context.

Design: We analyzed data from the population-based Study of Health in Pomerania.

Methods: We used data from 3863 subjects (1971 women) aged 20-79 years who had no history of viral hepatitis, liver cirrhosis, or malignant diseases. Liver hyperechogenicity was diagnosed using ultrasound. Serum IGF1 and IGFBP-3 levels were determined by automated two-site chemiluminescence immunoassays.

Results: Hyperechogenic liver pattern was associated with low serum IGF1 levels and low serum IGF1/IGFBP-3 ratios. The lowest serum IGF1 and IGF1/IGFBP-3 values and highest IGFBP-3 levels were present in subjects who had a hyperechogenic liver pattern and increased serum ALT levels. All of these associations were independent of alcohol consumption.

Conclusions: Our data show that hepatic steatosis is associated with low serum IGF1 levels. This association is independent of alcohol consumption.
\end{abstract}

European Journal of Endocrinology 161 705-713

\section{Introduction}

There is accumulating evidence that hepatic steatosis is tightly associated with several metabolic (1-5) and cardiovascular disorders (6-8). In the majority of previous epidemiological studies the definition of the exposure variable was based exclusively on serum markers of hepatic steatosis including $\gamma$-glutamyl transpeptidase (GGT). Although the relationship between intracellular GGT and serum GGT levels has not been fully elucidated, it is assumed that high serum GGT levels are a marker of oxidative stress (9). The specificity of serum GGT levels for non-alcoholic hepatic steatosis is further limited by the fact that serum GGT levels are often related to alcohol consumption. While invasive liver biopsy as the gold standard to diagnose hepatic steatosis is not suitable for epidemiological research, both serum alanine aminotransaminase (ALT) levels and liver ultrasound, for which a relatively high sensitivity and specificity to diagnose hepatic steatosis have been demonstrated $(10,11)$, might be used as sufficient approximation to define hepatic steatosis in population research. However, epidemiological studies that included serum ALT levels and hepatic ultrasound on the one hand as well as intense cardiometabolic characterization of their subjects on the other hand are scant.

Animals with liver-specific insulin-like growth factor1 (IGF1) gene deletion are characterized by insulin resistance and hyperinsulinemia $(12,13)$. Low serum IGF1 levels are also associated with determinants of the metabolic syndrome including insulin resistance, serum leptin levels, waist-to-hip ratio, and type 2 diabetes mellitus (14-18). Moreover, low baseline levels of serum IGF1 predict an increased risk of fatal coronary events (19). IGF1 substitution leads to a decrease in body fat and serum-insulin concentrations and an increase in lean body mass (20). Since serum IGF1 is mainly produced in the liver (21), a hypothetical decrease in serum IGF1 levels in individuals with hepatic steatosis 
would represent a common pathway linking hepatic steatosis to the metabolic syndrome and atherosclerosis. Experimental evidence suggests that hepatic steatosis following high-calorie total parenteral nutrition reduces the abundance of hepatic IGF1 mRNA (22). The question of whether hepatic steatosis is associated with decreased serum IGF1 levels in humans has not yet attracted sufficient attention.

In the circulating blood, most of the IGF1 is bound to serum IGF binding protein-3 (IGFBP-3), which therefore lowers the bioavailability of IGF1 (23). Increased serum IGFBP-3 levels have been reported from experimental hepatic steatosis models (22) and might intensify biological effects of IGF1 deficiency in liver disorders. As with IGF1, the association between serum IGFBP-3 levels and hepatic steatosis is currently not well documented in human populations.

The aims of the present study were i) to investigate the associations between hepatic steatosis and serum IGF1 as well as IGFBP-3 levels using ultrasound and serum ALT levels to define hepatic steatosis and ii) to analyze the specific role of alcohol consumption in this context. To achieve these aims, we utilized data from the population-based Study of Health in Pomerania (SHIP).

\section{Methods}

\section{Study population}

SHIP is a cross-sectional population-based study in West Pomerania, a region in the northeast of Germany. Study details are given elsewhere $(7,24)$. In brief, the total population comprised 212157 inhabitants. A sample from the population aged 20-79 years was drawn. The sample was selected using population registries, where all German inhabitants are registered. Only individuals with German citizenship and principal residency in the study area were included. The net sample (after exclusion of migrated or deceased persons) comprised 6267 eligible subjects. The SHIP population finally comprised 4310 participants (2193 women), corresponding to a final response of $68.8 \%$. The study was reviewed by a board of independent scientists and approved by the Ethics Committee of the University of Greifswald. All participants gave written informed consent.

A total of 447 (221 women) subjects were excluded from the study for either variables that might have biased the present study or missing data on liver ultrasound or serum IGF1 or IGFBP-3 levels. Since some individuals met more than one exclusion criterion, the following numbers total to more than 4310 subjects ( 2193 women). There were 55 subjects ( 24 women) seropositive for hepatitis B virus (HBsAg) or hepatitis $\mathrm{C}$ virus (anti-HCV) or with previous history of hepatitis or liver cirrhosis. Additionally, 37 subjects (15 women) reported a history of malignant disease, and 18 women were pregnant. Among the remaining, 45 subjects ( 22 women) had missing liver ultrasound or uncertain sonographic liver echogenicity. All of these participants and an additional 297 subjects (143 women) with no blood drawn or missing data on serum IGF1 or ALT for other reasons were excluded from this study. This resulted in a study population of 3863 subjects (1971 women) available for the present analysis.

\section{Measurements}

Socio-demographic and medical characteristics were assessed by computer-assisted personal interviews. Diabetes mellitus was defined as a self-reported physician's diagnosis of diabetes. Alcohol intake during the previous week was used as a proxy for general intake, and the mean daily alcohol consumption was calculated using beverage-specific pure ethanol volume proportions (25). Regarding the mean daily alcohol consumption, subjects were divided into two categories $(<20$ and $\geq 20 \mathrm{~g} /$ day $)$. Height and weight were measured for the calculation of the body mass index $\left(\mathrm{BMI}=\right.$ weight $(\mathrm{kg}) /$ height $\left.^{2}\left(\mathrm{~m}^{2}\right)\right)$. Overweight was defined as a BMI of $\geq 25 \mathrm{~kg} / \mathrm{m}^{2}$ and obesity as a BMI of $\geq 30 \mathrm{~kg} / \mathrm{m}^{2}$. We used waist circumference as an indicator of abdominal obesity. The cut-off points for waist circumference were $>102 \mathrm{~cm}$ in men and $>88 \mathrm{~cm}$ in women (26).

Non-fasting blood samples were drawn from the cubital vein in the supine position. The two analytical laboratories involved in this study participated at least semiannually in the official national German tests for quality assurance. In addition, internal quality materials were analyzed daily. Serum liver enzyme levels were measured photometrically (Hitachi 704, Roche). Serum liver enzyme levels exceeding the upper reference limit recommended by the manufacturer (aspartate aminotransaminase, AST: $0.62 \mu \mathrm{mol} / \mathrm{l}$ per s in men and $0.52 \mu \mathrm{mol} / \mathrm{l}$ per $\mathrm{s}$ in women; ALT: $0.67 \mu \mathrm{mol} / \mathrm{l}$ per $\mathrm{s}$ in men and $0.52 \mu \mathrm{mol} / \mathrm{l}$ per $\mathrm{s}$ in women; GGT: $0.82 \mu \mathrm{mol} / \mathrm{l}$ per s in men and $0.53 \mu \mathrm{mol} / \mathrm{l}$ per $\mathrm{s}$ in women) were considered increased. The mean corpuscular volume (MCV) of the erythrocytes was determined by measurements of electrical resistance (Coulter Electronics, Hialeah, FL, USA). Serum levels of carbohydrate-deficient transferrin (CDT) were measured by an immunoassay (Cobas Mira, Roche). Markers of HBsAg and anti-HCV infection were analyzed by ELISAs (AxSym HBSAG and AxSym HCV, Abbott).

Serum IGF1 and IGFBP-3 levels were determined by automated two-site chemiluminescence immunoassays (Nichols Advantage; Nichols Institute Diagnostica $\mathrm{GmbH}$, Bad Vilbel, Germany). All serum samples were acidified to separate IGF1 from IGFBPs. The analytical sensitivity of the IGF1 assay was $6 \mathrm{ng} / \mathrm{ml}$, the intraassay imprecision within the range of $63-766 \mathrm{ng} / \mathrm{ml}$ was $4.8 \%$, and inter-assay imprecision within the range 
of $62-811 \mathrm{ng} / \mathrm{ml}$ was $6.7 \%$. The IGF1 assay has been calibrated against the World Health Organization International Reference Reagent 1988, IGF1 87/518. Serum IGF1 levels below the 25th percentile were considered decreased. The analytical sensitivity of the IGFBP-3 assay was $20 \mathrm{ng} / \mathrm{ml}$. The intra- and inter-assay imprecisions within the range of $227-2703 \mathrm{ng} / \mathrm{ml}$ were 5.8 and $11 \%$, respectively. The assay reference standard was analytically prepared with glycosylated recombinant human IGFBP-3. Only one lot of reagents was used for all IGFBP-3 measurements. Increased serum IGFBP3 concentrations were defined as levels above the 75 th percentile. The serum IGF1/IGFBP-3 ratio was calculated, and values below the 25 th percentile were considered decreased.

Trained physicians examined the liver using a $5 \mathrm{MHz}$ transducer and a high-resolution instrument (Vingmed VST Gateway, Santa Clara, CA, USA). The sonographers were unaware of the participants' clinical and laboratory characteristics. A hyperechogenic pattern was defined as the presence of an ultrasonographic pattern of a bright liver, with evident contrast between hepatic and renal parenchyma $(27,28)$.

\section{Statistical analyses}

The study population was divided into four categories using ultrasound findings and laboratory data (29). Categories 1 and 2 included subjects without hyperechogenic liver pattern without (1) and with increased serum ALT levels (2). Categories 3 and 4 included subjects with hyperechogenic liver pattern without (3) and with increased serum ALT levels (4). Data on quantitative characteristics are expressed as median (25th and 75th percentiles). Data on qualitative characteristics are expressed as percent values or absolute numbers as indicated. Multivariable statistical analyses were performed using ANOVA (continuously distributed dependent variables) or logistic regression analysis (dichotomized-dependent variables). Adjusted means and odds ratios and their 95\% confidence intervals $(95 \% \mathrm{CI})$ are given. A value of $P<0.05$ was considered statistically significant. All statistical analyses were performed with SPSS software, version 14.0.1 (SPSS GmbH Software, Munich, Germany).

\section{Results}

There were 1173 subjects (30.4\%) with hyperechogenic pattern of the liver on ultrasound (Table 1). Of these, 706 subjects $(60.2 \%)$ had serum ALT levels within the reference range, and 467 subjects (39.8\%) had increased serum ALT levels. Among the 2690 subjects $(69.6 \%)$ without a hyperechogenic pattern of the liver, $2400(89.2 \%)$ had serum ALT levels within the reference range, and 290 subjects (10.8\%) had increased serum ALT levels.

There were several differences in demographic and clinical characteristics between subjects with and without liver hyperechogenicity (Table 1). Thus, the former were older, had a higher BMI, and more frequently increased waist circumferences than the latter. As a group, subjects with liver hyperechogenicity had higher proportions of male, obese, and diabetic individuals respectively. Furthermore, subjects with liver hyperechogenicity had lower serum IGF1 levels and IGF1/IGFBP-3 ratios than subjects without liver hyperechogenicity. The two groups did not differ significantly with respect to serum IGFBP-3 levels.

Age- and sex-adjusted analyses confirmed that subjects with hyperechogenic liver pattern had lower

Table 1 Selected characteristics of subjects with different combinations of ultrasound and serum alanine aminotransaminase (ALT) findings.

\begin{tabular}{|c|c|c|c|c|}
\hline & Ultrasound - ALT - & Ultrasound - ALT+ & Ultrasound + ALT - & Ultrasound + ALT + \\
\hline$n$ & 2400 & 290 & 706 & 467 \\
\hline Sex (male) & $41.1 \%$ & $62.8 \%$ & $56.5 \%$ & $69.6 \%$ \\
\hline BMI $\left(\mathrm{kg} / \mathrm{m}^{2}\right)$ & $25.4(22.7 ; 28.4)$ & $27.4(25.2 ; 29.8)$ & $29.3(26.5 ; 32.1)$ & $30.3(27.6 ; 33.6)$ \\
\hline $\mathrm{BMI} \geq 25 \mathrm{~kg} / \mathrm{m}^{2}$ & $37.9 \%$ & $54.5 \%$ & $41.6 \%$ & $40.3 \%$ \\
\hline $\mathrm{BMI} \geq 30 \mathrm{~kg} / \mathrm{m}^{2}$ & $15.5 \%$ & $22.4 \%$ & $43.5 \%$ & $53.0 \%$ \\
\hline Increased waist* & $19.2 \%$ & $26.6 \%$ & $49.5 \%$ & $59.5 \%$ \\
\hline Diabetes mellitus & $3.9 \%$ & $5.5 \%$ & $16.5 \%$ & $16.1 \%$ \\
\hline Alcohol consumption $\geq 20 \mathrm{~g} /$ day & $26.8 \%$ & $40.8 \%$ & $29.5 \%$ & $50.0 \%$ \\
\hline $\operatorname{MCV}\left(\mu \mathrm{m}^{3}\right)$ & $90.0(87.5 ; 92.4)$ & $90.0(88.0 ; 92.9)$ & $90.0(87.7 ; 93.0)$ & $91.0(88.2 ; 93.9)$ \\
\hline Serum CDT (\%) & $4.60(3.86 ; 5.50)$ & $4.40(3.72 ; 5.41)$ & $4.50(3.74 ; 5.48)$ & $4.60(3.78 ; 5.60)$ \\
\hline Serum ALT levels ( $\mu \mathrm{mol} / \mathrm{l}$ per $\mathrm{s}$ ) & $0.32(0.25 ; 0.42)$ & $0.76(0.66 ; 0.90)$ & $0.41(0.34 ; 0.49)$ & $0.86(0.72 ; 1.11)$ \\
\hline Serum AST levels ( $\mu \mathrm{mol} / \mathrm{l}$ per $\mathrm{s})$ & $0.30(0.26 ; 0.35)$ & $0.44(0.38 ; 0.53)$ & $0.33(0.28 ; 0.38)$ & $0.50(0.42 ; 0.63)$ \\
\hline Serum GGT levels ( $\mu \mathrm{mol} / \mathrm{l}$ per $\mathrm{s})$ & $0.27(0.20 ; 0.40)$ & $0.57(0.37 ; 0.91)$ & $0.39(0.29 ; 0.63)$ & $0.77(0.48 ; 1.42)$ \\
\hline Serum IGF1 (ng/ml) & $141(110 ; 180)$ & $144(116 ; 190)$ & $113(88 ; 148)$ & $111(87 ; 143)$ \\
\hline IGF1/IGFBP-3 ratio & $0.076(0.061 ; 0.092)$ & $0.074(0.060 ; 0.094)$ & $0.064(0.052 ; 0.082)$ & $0.060(0.047 ; 0.073)$ \\
\hline
\end{tabular}

Data are given as percentage or median (25th; 75 th quartile). ${ }^{*}>102 \mathrm{~cm}$ in men, $>88 \mathrm{~cm}$ in women. BMI, body mass index; MCV, mean corpuscular volume; CDT, carbohydrate deficient transferrin; ALT, alanine aminotransaminase; AST, aspartate aminotransaminase; GGT, $\gamma$-glutamyl transpeptidase; IGF, insulin-like growth factor; IGFBP, insulin-like growth factor binding protein. 
Table 2 Association between liver disorders and serum insulin-like growth factor-1 (IGF1) levels.

\begin{tabular}{|c|c|c|c|c|}
\hline & Ultrasound-ALT- & Ultrasound $-\mathbf{A L T}+$ & Ultrasound + ALT - & Ultrasound + ALT + \\
\hline Serum IGF1; ng/ml, adjusted for age and sex & $146(145 ; 149)$ & $143(138 ; 149)$ & $138(134 ; 142)^{*}$ & $123(119 ; 128)^{*}$ \\
\hline $\begin{array}{l}\text { Serum IGF1; ng/ml, adjusted for age, sex, } \\
\text { BMI, increased waist, and diabetes }\end{array}$ & $146(143 ; 150)$ & $143(137 ; 149)$ & $138(134 ; 143)^{*}$ & $124(119 ; 129)^{*}$ \\
\hline $\begin{array}{l}\text { Serum IGF1; ng/ml, adjusted for age, sex, } \\
\text { BMI, increased waist, diabetes, } \\
\text { and alcohol use }\end{array}$ & $145(142 ; 149)$ & $142(136 ; 149)$ & $137(133 ; 142)^{*}$ & $124(119 ; 129)$ * \\
\hline $\begin{array}{l}\text { Serum IGF1; ng/ml, adjusted for age, sex, } \\
\text { BMI, increased waist, diabetes, alcohol } \\
\text { use, and IGFBP-3 }\end{array}$ & $147(144 ; 151)$ & $143(137 ; 148)$ & $138(135 ; 144)^{*}$ & $133(127 ; 139)^{*}$ \\
\hline $\begin{array}{l}\text { Decreased serum IGF1, adjusted for } \\
\text { age and sex }\end{array}$ & 1.0 (reference) & $1.41(0.99 ; 1.99)$ & $1.53(1.26 ; 1.87)^{\star}$ & $2.99(2.36 ; 3.78)^{\star}$ \\
\hline $\begin{array}{l}\text { Decreased serum IGF1, adjusted for } \\
\text { age, sex, BMI, increased waist, } \\
\text { and diabetes }\end{array}$ & 1.0 (reference) & $1.41(0.99 ; 2.00)$ & $1.46(1.19 ; 1.80)^{\star}$ & $2.78(2.16 ; 3.57)^{\star}$ \\
\hline $\begin{array}{l}\text { Decreased serum IGF1, adjusted for } \\
\text { age, sex, BMI, increased waist, } \\
\text { diabetes, and alcohol use }\end{array}$ & 1.0 (reference) & $1.39(0.98 ; 1.98)$ & $1.46(1.19 ; 1.80)^{\star}$ & $2.71(2.10 ; 3.49)^{\star}$ \\
\hline $\begin{array}{l}\text { Decreased serum IGF1, adjusted for age, } \\
\text { sex, BMI, alcohol use, increased waist, } \\
\text { diabetes, and IGFBP-3 }\end{array}$ & 1.0 (reference) & $1.37(0.92 ; 2.02)$ & $1.63(1.30 ; 2.04)^{\star}$ & $3.74(2.82 ; 4.96)^{\star}$ \\
\hline
\end{tabular}

${ }^{\star} P<0.05$ compared with subjects without hyperechogenic liver pattern and ALT levels within the reference range; ANOVA (serum IGF1 levels) and logistic regression (decreased serum IGF1 levels). Data are given as adjusted mean ( $95 \%$ confidence interval) and odds ratio (95\% confidence interval). Serum IGF1 levels below the 25th percentile were considered decreased. ALT, alanine aminotransaminase; BMI, body mass index, IGF, insulin-like growth factor.

serum IGF1 levels than subjects with no liver disorders, with subjects with hyperechogenic liver pattern and increased serum ALT levels showing the lowest IGF1 values (Table 2). Additional adjustments for BMI, increased waist circumference, diabetes, alcohol consumption, and serum IGFBP-3 levels did not substantially change these results. Logistic regression analyses using decreased serum IGF1 levels as dichotomizeddependent variables yielded similar results. Subjects with liver hyperechogenicity had higher odds for decreased serum IGF1 levels than subjects without liver hyperechogenicity. Among subjects with hyperechogenicity, those with increased serum ALT levels had the highest odds for decreased IGF1 levels (Table 2).

In contrast to serum IGF1 levels, serum IGFBP-3 levels were not consistently significantly affected in subjects with liver hyperechogenicity (Table 3). Over all models, only subjects with both liver hyperechogenicity and increased serum ALT levels had higher serum IGFBP-3 levels and higher odds for increased serum IGFBP-3 levels relative to subjects without these liver findings.

Table 3 Association between liver disorders and serum insulin-like growth factor binding protein-3 (IGFBP-3) levels.

\begin{tabular}{|c|c|c|c|c|}
\hline & Ultrasound - ALT- & Ultrasound-ALT+ & Ultrasound + ALT - & Ultrasound + ALT + \\
\hline $\begin{array}{l}\text { Serum IGFBP-3; } \mathrm{mg} / \mathrm{ml} \text {, adjusted for age } \\
\text { and sex }\end{array}$ & $1.85(1.83 ; 1.87)$ & $1.91(1.86 ; 1.96)$ & $1.89(1.86 ; 1.93)^{\star}$ & $1.97(1.93 ; 2.02)^{\star}$ \\
\hline $\begin{array}{l}\text { Serum IGFBP-3; } \mathrm{mg} / \mathrm{ml} \text {, adjusted for } \\
\text { age, sex, BMI, increased waist, } \\
\text { and diabetes }\end{array}$ & $1.82(1.79 ; 1.86)$ & $1.87(1.81 ; 1.93)$ & $1.86(1.82 ; 1.90)$ & $1.93(1.88 ; 1.98)$ * \\
\hline $\begin{array}{l}\text { Serum IGFBP-3; } \mathrm{mg} / \mathrm{ml} \text {, adjusted for } \\
\text { age, sex, BMl, increased waist, } \\
\text { diabetes, and alcohol use }\end{array}$ & $1.84(1.80 ; 1.87)$ & $1.88(1.82 ; 1.94)^{\star}$ & $1.87(1.83 ; 1.91)$ & $1.94(1.89 ; 1.99)^{\star}$ \\
\hline $\begin{array}{l}\text { Increased serum IGFBP-3; mg/ml, } \\
\text { adjusted for age and sex }\end{array}$ & 1.0 (reference) & $1.75(1.33 ; 2.30)^{*}$ & $1.47(1.17 ; 1.84)^{\star}$ & $2.13(1.68 ; 2.70)^{\star}$ \\
\hline $\begin{array}{l}\text { Increased serum IGFBP-3; mg/ml, } \\
\text { adjusted for age, sex, BMI, increased } \\
\text { waist, and diabetes }\end{array}$ & 1.0 (reference) & $1.66(1.25 ; 2.19)^{\star}$ & $1.37(1.08 ; 1.73)^{\star}$ & $1.98(1.54 ; 2.55)^{\star}$ \\
\hline $\begin{array}{l}\text { Increased serum IGFBP-3; mg/ml, } \\
\text { adjusted for age, sex, BMI, increased } \\
\text { waist, diabetes, and alcohol use }\end{array}$ & 1.0 (reference) & $1.65(1.25 ; 2.18)^{*}$ & $1.37(1.08 ; 1.72)^{\star}$ & $1.95(1.51 ; 2.52)^{\star}$ \\
\hline
\end{tabular}

${ }^{\star} P<0.05$ compared with subjects without hyperechogenic liver pattern and ALT levels within the reference range; ANOVA (serum IGFBP-3 levels) and logistic regression (decreased serum IGFBP-3 levels). Data are given as adjusted mean (95\% confidence interval) and odds ratio (95\% confidence interval). Serum IGFBP3 levels above the 75th percentile were considered increased. ALT, alanine aminotransaminase; BMI, body mass index, IGFBP, insulin-like growth factor binding protein. 
Table 4 Association between liver disorders and serum insulin-like growth factor-1 (IGF1)/IGF binding protein -3 (IGFBP-3) ratio.

\begin{tabular}{|c|c|c|c|c|}
\hline & Ultrasound - ALT - & Ultrasound-ALT+ & Ultrasound + ALT- & Ultrasound + ALT + \\
\hline $\begin{array}{l}\text { IGF1/IGFBP-3 ratio, adjusted for } \\
\text { age and sex }\end{array}$ & $0.082(0.080 ; 0.083)$ & $0.081(0.076 ; 0.085)$ & $0.076(0.073 ; 0.079)^{*}$ & $0.065(0.061 ; 0.068)^{\star}$ \\
\hline $\begin{array}{l}\text { IGF1/IGFBP-3 ratio, adjusted for } \\
\text { age, sex, BMI, increased waist, } \\
\text { and diabetes }\end{array}$ & $0.082(0.080 ; 0.085)$ & $0.082(0.077 ; 0.087)$ & $0.077(0.074 ; 0.081)^{\star}$ & $0.066(0.062 ; 0.070)^{\star}$ \\
\hline $\begin{array}{l}\text { IGF1/IGFBP-3 ratio, adjusted for age, } \\
\text { sex, BMI, increased waist, diabetes, } \\
\text { and alcohol use }\end{array}$ & $0.081(0.078 ; 0.084)$ & $0.081(0.076 ; 0.086)$ & $0.076(0.072 ; 0.080)^{\star}$ & $0.066(0.062 ; 0.070)^{\star}$ \\
\hline $\begin{array}{l}\text { Decreased IGF1/IGFBP-3 ratio, adjusted } \\
\text { for age and sex }\end{array}$ & 1.0 (reference) & $1.47(1.06 ; 2.05)^{\star}$ & $1.82(1.48 ; 2.23)^{\star}$ & $4.42(3.49 ; 5.58)^{\star}$ \\
\hline $\begin{array}{l}\text { Decreased IGF1/IGFBP-3 ratio, adjusted } \\
\text { for age, sex, BMI, increased waist, } \\
\text { and diabetes }\end{array}$ & 1.0 (reference) & $1.43(1.02 ; 2.00)^{*}$ & $1.74(1.40 ; 2.15)^{*}$ & $4.07(3.17 ; 5.24)^{\star}$ \\
\hline $\begin{array}{l}\text { Decreased IGF1/IGFBP-3 ratio, adjusted } \\
\text { for age, sex, BMI, increased waist, } \\
\text { diabetes, and alcohol use }\end{array}$ & 1.0 (reference) & $1.39(0.99 ; 1.95)$ & $1.72(1.39 ; 2.13)^{\star}$ & $3.86(3.00 ; 4.97)^{\star}$ \\
\hline
\end{tabular}

${ }^{\star} P<0.05$ compared with subjects without hyperechogenic liver pattern and ALT levels within the reference range; ANOVA (IGF1/IGFBP-3 ratio) and logistic regression (decreased IGF1/IGFBP-3 ratio). Data are given as adjusted mean (95\% confidence interval) and odds ratio (95\% confidence interval). An IGF1/IGFBP-3 ratio below the 25th percentile was considered decreased. ALT, alanine aminotransaminase; BMI, body mass index, IGF, insulin-like growth factor, IGFBP, insulin-like growth factor binding protein.

Analyses using serum IGF1/IGFBP-3 ratio as the dependent variable yielded results similar to those obtained with analyses using serum IGF1 levels as the dependent variable (Table 4). Subjects with liver hyperechogenicity had lower serum IGF1/IGFBP-3 ratios than subjects without liver hyperechogenicity, with subjects with increased serum ALT levels having the lowest values. Subjects with liver hyperechogenicity also had higher odds for decreased IGF1/IGFBP-3 ratios than subjects without liver hyperechogenicity. Similar to the previous findings, subjects with liver hyperechogenicity and increased serum ALT levels had the highest odds for decreased IGF1/IGFBP-3 ratios (Table 4).

We repeated all multivariable analyses after stratifying the study population into subjects with alcohol consumption of $<20 \mathrm{~g} /$ day $(n=2657)$ and $\geq 20 \mathrm{~g} /$ day
( $n=1206)$ respectively. The relationship between hyperechogenicity and low serum IGF1 levels was present in both subgroups and was again strongest for the comparison between subjects with hyperechogenic liver pattern and increased serum ALT levels and subjects without liver disorders (Table 5). There were also no consistently different results between subjects with more or less alcohol consumption with respect to serum IGFBP-3 levels (Table 6). Analyses also arrived at similar results in both groups when the serum IGF1/IGFBP-3 ratio was used as an alternative dependent variable (Table 7).

In sensitivity analyses, we replaced information on alcohol consumption by serum values of CDT, AST/ALT ratio or MCV. Using these variables for both adjustment and stratification did not substantially affect the major results (data not shown).

Table 5 Association between liver disorders and serum insulin-like growth factor-1 (IGF1) levels in subjects with alcohol consumption of $<20$ and $\geq 20 \mathrm{~g} /$ day respectively.

\begin{tabular}{|c|c|c|c|c|}
\hline & Ultrasound $-\mathbf{A L T}-$ & Ultrasound $-\mathbf{A L T}+$ & Ultrasound + ALT - & Ultrasound $+\mathbf{A L T}+$ \\
\hline \multicolumn{5}{|l|}{ Alcohol consumption $<20 \mathrm{~g} /$ day } \\
\hline $\begin{array}{l}\text { Serum IGF1; ng/ml, adjusted for age, } \\
\text { sex, BMI, increased waist, diabetes, } \\
\text { and IGFBP-3 }\end{array}$ & $151(147 ; 155)$ & $150(143 ; 157)$ & $143(138 ; 147)^{\star}$ & $128(122 ; 134)^{*}$ \\
\hline $\begin{array}{l}\text { Decreased serum IGF1, adjusted } \\
\text { for age, sex, BMI, increased waist, } \\
\text { diabetes, and IGFBP-3 }\end{array}$ & 1.0 (reference) & $1.75(1.08 ; 2.83)^{*}$ & $1.53(1.17 ; 1.99)^{\star}$ & $3.37(2.31 ; 4.91)^{\star}$ \\
\hline \multicolumn{5}{|l|}{ Alcohol consumption $\geq 20 \mathrm{~g} /$ day } \\
\hline $\begin{array}{l}\text { Serum IGF1; ng/ml, adjusted for age, } \\
\text { sex, BMI, increased waist, diabetes, } \\
\text { and IGFBP-3 }\end{array}$ & $146(139 ; 153)$ & $136(126 ; 147)^{\star}$ & $134(125 ; 143)^{\star}$ & $119(110 ; 127)^{\star}$ \\
\hline $\begin{array}{l}\text { Decreased serum IGF1, adjusted for } \\
\text { age, sex, BMI, increased waist, } \\
\text { diabetes, and IGFBP-3 }\end{array}$ & 1.0 (reference) & $0.86(0.42 ; 1.78)$ & $1.93(1.26 ; 2.96)^{\star}$ & $3.44(2.20 ; 5.37)^{\star}$ \\
\hline
\end{tabular}


Table 6 Association between liver disorders and serum insulin-like growth factor binding protein-3 (IGFBP-3) levels in subjects with alcohol consumption of $<20$ and $\geq 20 \mathrm{~g} /$ day respectively.

\begin{tabular}{|c|c|c|c|c|}
\hline & Ultrasound-ALT- & Ultrasound-ALT + & Ultrasound + ALT - & Ultrasound + ALT + \\
\hline \multicolumn{5}{|l|}{ Alcohol consumption $<20 \mathrm{~g} /$ day } \\
\hline $\begin{array}{l}\text { Serum IGFBP-3; mg/ml, adjusted for } \\
\text { age, sex, BMI, increased waist, } \\
\text { and diabetes }\end{array}$ & $1.80(1.77 ; 1.84)$ & $1.83(1.75 ; 1.90)$ & $1.84(1.79 ; 1.89)$ & $1.97(1.90 ; 2.03)^{*}$ \\
\hline $\begin{array}{l}\text { Decreased serum IGFBP-3, adjusted } \\
\text { for age, sex, BMI, increased waist, } \\
\text { and diabetes }\end{array}$ & 1.0 (reference) & $1.59(1.11 ; 2.28)^{*}$ & $1.14(0.86 ; 1.52)$ & $2.13(1.52 ; 2.98)^{*}$ \\
\hline \multicolumn{5}{|l|}{ Alcohol consumption $\geq 20 \mathrm{~g} /$ day } \\
\hline $\begin{array}{l}\text { Serum IGFBP-3; } \mathrm{mg} / \mathrm{ml} \text {, adjusted for } \\
\text { age, sex, BMI, increased waist, } \\
\text { and diabetes }\end{array}$ & $1.83(1.76 ; 1.91)$ & $1.88(1.77 ; 1.99)$ & $1.86(1.77 ; 1.95)$ & $1.83(1.75 ; 1.92)$ \\
\hline $\begin{array}{l}\text { Decreased serum IGFBP-3, adjusted } \\
\text { for age, sex, BMI, increased waist, } \\
\text { and diabetes }\end{array}$ & 1.0 (reference) & $1.65(1.05 ; 2.60)^{\star}$ & $1.97(1.28 ; 3.03)^{*}$ & $1.56(1.03 ; 2.34)^{\star}$ \\
\hline
\end{tabular}

${ }^{*} P<0.05$ compared with subjects without hyperechogenic liver pattern and ALT levels within the reference range; ANOVA (serum IGF1 levels) and logistic regression (decreased serum IGF1 levels). Data are given as adjusted mean ( $95 \%$ confidence interval) and odds ratio (95\% confidence interval). Serum IGFBP-3 levels above the 75th percentile were considered increased. ALT, alanine aminotransaminase; BMI, body mass index, IGFBP, insulin-like growth factor binding protein.

\section{Discussion}

We studied the relationship of hepatic steatosis with serum IGF1 and IGFBP-3 levels using data from a population-based study. Hepatic steatosis as evidenced by a hyperechogenic liver pattern was associated with low serum IGF1 levels and low serum IGF1/IGFBP-3 ratios. This relation was observed in subjects with and without increased serum ALT enzyme levels. However, the lowest serum IGF1 and IGF1/IGFBP-3 values were present in subjects who had a hyperechogenic liver pattern and increased serum ALT levels. These results indicate that low serum IGF1 levels contribute to the association between hepatic steatosis and the metabolic syndrome.
Serum IGFBP-3 levels were also slightly increased in this group. All of these associations were independent of alcohol consumption.

The findings of our study are in line with the results of a smaller clinical study (30) that demonstrated lower serum IGF1 levels in 34 patients with chronic liver diseases due to viral hepatitis and 12 healthy controls. Compared to controls, serum IGF1 levels were 2.5 times lower in patients with uncomplicated hepatitis and 8.5 times lower in patients with histological evidence for liver cirrhosis (30). On the other hand, hepatic steatosis is also common in patients with GH deficiency, and GH substitution might ameliorate hepatic steatosis $(31,32)$. Thus, the association between hepatic steatosis and low

Table 7 Association between liver disorders and serum insulin-like growth factor-1 (IGF1)/IGF binding protein-3 (IGFBP-3) ratio in subjects with alcohol consumption of $<20$ and $\geq 20$ g/day respectively.

\begin{tabular}{|c|c|c|c|c|}
\hline & Ultrasound - ALT - & Ultrasound $-\mathbf{A L T}+$ & Ultrasound + ALT - & Ultrasound + ALT + \\
\hline \multicolumn{5}{|l|}{ Alcohol consumption $<20 \mathrm{~g} /$ day } \\
\hline $\begin{array}{l}\text { IGF1/IGFBP-3 ratio, adjusted for } \\
\text { age, sex, BMI, increased waist, } \\
\text { and diabetes }\end{array}$ & $0.085(0.081 ; 0.088)$ & $0.087(0.080 ; 0.093)$ & $0.078(0.074 ; 0.082)^{\star}$ & $0.068(0.063 ; 0.074)^{*}$ \\
\hline $\begin{array}{l}\text { Decreased IGF1/IGFBP-3 ratio, } \\
\text { adjusted for age, sex, BMI, } \\
\text { increased waist, and diabetes }\end{array}$ & 1.0 (reference) & $1.12(0.72 ; 1.24)$ & $1.47(1.14 ; 1.90)^{*}$ & $3.22(2.30 ; 4.52)^{\star}$ \\
\hline \multicolumn{5}{|l|}{ Alcohol consumption $\geq 20 \mathrm{~g} /$ day } \\
\hline $\begin{array}{l}\text { IGF1/IGFBP-3 ratio, adjusted for } \\
\text { age, sex, BMI, increased waist, } \\
\text { and diabetes }\end{array}$ & $0.077(0.071 ; 0.083)$ & $0.075(0.066 ; 0.083)$ & $0.075(0.068 ; 0.083)$ & $0.065(0.058 ; 0.072)^{\star}$ \\
\hline $\begin{array}{l}\text { Decreased IGF1/IGFBP-3 ratio, } \\
\text { adjusted for age, sex, BMI, } \\
\text { increased waist, and diabetes }\end{array}$ & 1.0 (reference) & $1.86(1.09 ; 3.17)^{\star}$ & $2.51(1.67 ; 3.77)^{*}$ & $4.38(2.92 ; 6.55)^{\star}$ \\
\hline
\end{tabular}

${ }^{\star} P<0.05$ compared with subjects without hyperechogenic liver pattern and ALT levels within the reference range; ANOVA serum IGF1/IGFBP-3 ratio) and logistic regression (decreased serum IGF1/IGFBP-3 ratio). Data are given as adjusted mean (95\% confidence interval) and odds ratio (95\% confidence interval). Serum IGF1/IGFBP-3 ratio values below the 25th percentile were considered decreased. ALT, alanine aminotransaminase; BMI, body mass index, IGF, insulin-like growth factor, IGFBP, insulin-like growth factor binding protein. 
serum IGF1 levels might be bidirectional. Given the cross-sectional design of our study, we currently cannot decide whether there might be a cause-andeffect relation between the two factors.

It is currently believed that only the free form of IGF1 crosses the capillary boundaries to reach the target cells and is therefore biologically active. The serum IGF1/IGFBP-3 ratio may represent an approximation of free serum IGF1 (33). The suitability of serum IGF1 levels versus IGF1/IGFBP-3 ratios to best predict the metabolic syndrome and its cardiovascular sequelae remains to be determined. Our results from serum IGF1/IGFBP-3 ratios paralleled serum IGF1 levels, suggesting that serum IGFBP-3 levels may not have an additional predictive value.

In contrast to serum IGF1 levels and IGF1/IGFBP-3 ratios, serum IGFBP-3 levels were increased in subjects with hyperechogenic liver pattern and increased serum ALT levels. This observation suggests that IGFBP-3 production by hepatocytes (34) and Kupffer cells (35) may be less affected or even increased in subjects with fatty liver. While the exact mechanisms have to be established by experimental research, one may hypothesize that the combination of low IGF1 and high IGFBP-3 in individuals with hepatic steatosis acts to downregulate the biologically active free IGF1. However, reverse causality might also be present: the specific constellation of low serum IGF1 and high IGFBP-3 levels might have given rise to the highest risk of developing fatty liver disease.

The association between hepatic steatosis and serum IGF1 levels was similar in subjects with low and high daily alcohol consumptions respectively. Also sensitivity analyses, which were conducted to reduce the risk of information bias by replacing self-reported alcohol consumption by objective markers of alcohol misuse, did not affect the major findings. Intervention studies demonstrated that both alcohol withdrawal (36) and an optimized diet with low content of total fat and refined carbohydrates (37) increases serum IGF1 levels in treated subjects. Thus, with respect to serum IGF1 levels and probably also with respect to the risk of metabolic syndrome, the cause of hepatic steatosis might be less important than hepatic steatosis itself.

Further research is needed to explore the molecular mechanisms underlying the association between hepatic steatosis and low serum IGF1 levels. It has been suggested that low serum IGF1 concentrations may provide inadequate negative feedback control of hormone release at the level of the hypothalamus or the pituitary gland resulting in enhanced $\mathrm{GH}$ release (18). In early stages of chronic liver diseases, acquired $\mathrm{GH}$ resistance was observed, which worsened in parallel with the progression of liver disease (30). This mechanism, however, has been established only for clinically manifest viral hepatitis. Evidence for acquired GH resistance as an explanation for low serum IGF1 levels in mostly subclinical hepatic steatosis is pending.
The population-based design, the large study population, and the comprehensive characterization of the participants are strengths of the present study. Two limitations have to be considered. First, this investigation shares with others the limitations inherent to cross-sectional studies. Although the association between hepatic steatosis and serum IGF1 levels was strong and robust against various statistical models, the lack of time sequence precludes a causal interpretation. Consequently, the clinical relevance of our findings needs to be corroborated by further research, using data from longitudinal or intervention studies. Second, we have collected information on liver hyperechogenicity as a qualitative variable only. It would be interesting to see whether the association described herein remains present over the continuum of fatty liver disease. Methods like magnet resonance spectroscopy, which allow quantitative analyses of liver fat, have already been integrated in epidemiological studies (38), and may help answer this question in the near future.

We conclude that hepatic steatosis is associated with low serum IGF1 levels. This association is independent of alcohol consumption.

\section{Declaration of interest}

We declare that there is no conflict of interest that could be perceived as prejudicing the impartiality of the research reported.

\section{Funding}

The work is part of the Community Medicine Research net (CMR) of the University of Greifswald, Germany, which is funded by the Federal Ministry of Education and Research, the Ministry of Cultural Affairs as well as the Social Ministry of the Federal State of Mecklenburg-West Pomerania. The CMR encompasses several research projects which share data from the population-based Study of Health in Pomerania (SHIP; http://ship.community-medicine.de). Statistical analyses were supported by the GANI-MED project (03IS2061A) and Competence Network Diabetes of the German Federal Ministry of Education and Research. Analysis of serum IGF1 and IGFBP-3 levels was further supported by Pfizer Inc. New York, NY, USA. The funding sources were not involved in design and conduct of the study; collection, management, analysis, and interpretation of the data; and preparation, review, or approval of the manuscript.

\section{Author contribution statement}

$\mathrm{H}$ Völzke conducted the statistical analyses and wrote the manuscript. $\mathrm{H}$ Völzke, M Nauck, and H Wallaschofski received the funding for this study. All authors contributed to the concept of the study, revised the manuscript for important intellectual content and approved the final version.

\section{Acknowledgements}

Henry Völzke accepts full responsibility for the conduct of the study.

\section{References}

1 Meisinger C, Lowel H, Heier M, Schneider A \& Thorand B. Serum $\gamma$-glutamyltransferase and risk of type 2 diabetes mellitus in men and women from the general population. Journal of Internal Medicine $2005258527-535$. 
2 Lee DH, Jacobs DR Jr, Gross M, Kiefe CI, Roseman J, Lewis CE \& Steffes M. $\gamma$-Glutamyltransferase is a predictor of incident diabetes and hypertension: the Coronary Artery Risk Development in Young Adults (CARDIA) Study. Clinical Chemistry 200349 $1358-1366$.

3 Lee DH, Ha MH, Kim JH, Christiani DC, Gross MD, Steffes M, Blomhoff R \& Jacobs DR Jr. $\gamma$-Glutamyltransferase and diabetes - a 4 year follow-up study. Diabetologia 200346 359-364.

4 Lee DH, Silventoinen K, Jacobs DR Jr, Jousilahti P \& Tuomileto J. $\gamma$-Glutamyltransferase, obesity, and the risk of type 2 diabetes: observational cohort study among 20,158 middle-aged men and women. Journal of Clinical Endocrinology and Metabolism 200489 5410-5414.

5 Perry IJ, Wannamethee SG \& Shaper AG. Prospective study of serum $\gamma$-glutamyltransferase and risk of NIDDM. Diabetes Care $199821732-737$.

6 Meisinger C, Doring A, Schneider A \& Lowel H. Serum $\gamma$-glutamyltransferase is a predictor of incident coronary events in apparently healthy men from the general population. Atherosclerosis 2006189 297-302.

7 Volzke H, Robinson DM, Schminke U, Ludemann J, Rettig R, Felix SB, Kessler C, John U \& Meng W. Thyroid function and carotid wall thickness. Journal of Clinical Endocrinology and Metabolism 200489 2145-2149.

8 Lee DH, Silventoinen K, Hu G, Jacobs DR Jr, Jousilahti P, Sundvall J $\&$ Tuomilehto J. Serum $\gamma$-glutamyltransferase predicts non-fatal myocardial infarction and fatal coronary heart disease among 28,838 middle-aged men and women. European Heart Journal 200627 2170-2176.

9 Lee DH, Blomhoff R \& Jacobs DR Jr. Is serum $\gamma$ glutamyltransferase a marker of oxidative stress? Free Radical Research 200438 535-539.

10 Joseph AE, Saverymuttu SH, al-Sam S, Cook MG \& Maxwell JD. Comparison of liver histology with ultrasonography in assessing diffuse parenchymal liver disease. Clinical Radiology 199143 26-31.

11 Campos GM, Bambha K, Vittinghoff E, Rabl C, Posselt AM, Ciovica R, Tiwari U, Ferrel L, Pabst M, Bass NM \& Merriman RB. A clinical scoring system for predicting nonalcoholic steatohepatitis in morbidly obese patients. Hepatology 2008 47 1916-1923.

12 Yakar S, Liu JL, Fernandez AM, Wu Y, Schally AV, Frystyk J, Chernausek SD, Mejia W \& Le Roith D. Liver-specific IGF-1 gene deletion leads to muscle insulin insensitivity. Diabetes 200150 1110-1118.

13 Sjogren K, Wallenius K, Liu JL, Bohlooly YM, Pacini G, Svensson L, Törnell J, Isaksson OG, Ahrén B, Jansson JO \& Ohlsson C. Liverderived IGF-I is of importance for normal carbohydrate and lipid metabolism. Diabetes 200150 1539-1545.

14 Gomez JM, Maravall FJ, Gomez N, Navarro MA, Casamitjana R \& Soler J. Interactions between serum leptin, the insulin-like growth factor-I system, and sex, age, anthropometric and body composition variables in a healthy population randomly selected. Clinical Endocrinology $2003 \mathbf{5 8} 213-219$.

15 Sandhu MS, Heald AH, Gibson JM, Cruickshank JK, Dunger DB \& Wareham NJ. Circulating concentrations of insulin-like growth factor-I and development of glucose intolerance: a prospective observational study. Lancet 2002359 1740-1745.

16 Ciaraldi TP, Carter L, Rehman N, Mohideen P, Mudaliar S \& Henry RR. Insulin and insulin-like growth factor-1 action on human skeletal muscle: preferential effects of insulin-like growth factor-1 in type 2 diabetic subjects. Metabolism 200251 1171-1179.

17 Tong PC, Ho CS, Yeung VT, Ng MC, So WY, Ozaki R, Ko GT, Ma RC, Poon E, Chan NN, Lam CW \& Chan JC. Association of testosterone, insulin-like growth factor-I, and C-reactive protein with metabolic syndrome in Chinese middle-aged men with a family history of type 2 diabetes. Journal of Clinical Endocrinology and Metabolism $2005906418-6423$.

18 Sesti G, Sciacqua A, Cardellini M, Marini MA, Maio R, Vatrano M, Succurro E, Lauro R, Federici M \& Perticone F. Plasma concentration of IGF-I is independently associated with insulin sensitivity in subjects with different degrees of glucose tolerance. Diabetes Care 200528 120-125.

19 Laughlin GA, Barrett-Connor E, Criqui MH \& Kritz-Silverstein D. The prospective association of serum insulin-like growth factor I (IGF-I) and IGF-binding protein-1 levels with all cause and cardiovascular disease mortality in older adults: the Rancho Bernardo Study. Journal of Clinical Endocrinology and Metabolism 200489 114-120.

20 Mauras N, Martinez V, Rini A \& Guevara-Aguirre J. Recombinant human insulin-like growth factor I has significant anabolic effects in adults with growth hormone receptor deficiency: studies on protein, glucose, and lipid metabolism. Journal of Clinical Endocrinology and Metabolism 200085 3036-3042.

21 Yakar S, Liu JL, Stannard B, Butler A, Accili D, Sauer B \& LeRoith D. Normal growth and development in the absence of hepatic insulin-like growth factor I. PNAS 199996 7324-7329.

22 Ney DM, Yang H, Smith SM \& Unterman TG. High-calorie total parenteral nutrition reduces hepatic insulin-like growth factor-I mRNA and alters serum levels of insulin-like growth factorbinding protein-1, -3, -5, and -6 in the rat. Metabolism $1995 \mathbf{4 4}$ $152-160$.

23 Rajaram S, Baylink DJ \& Mohan S. Insulin-like growth factorbinding proteins in serum and other biological fluids: regulation and functions. Endocrine Reviews 199718 801-831.

24 John U, Greiner B, Hensel E, Ludemann J, Piek M, Sauer S, Adam C, Born G, Alte D, Greiser E, Haertel U, Hense HW, Haerting J, Willich S \& Kessler C. Study of Health in Pomerania (SHIP): a health examination survey in an east German region: objectives and design. Sozial- und Práventivmedizin 200146 186-194.

25 Alte D, Ludemann J, Piek M, Adam C, Rose HJ \& John U. Distribution and dose response of laboratory markers to alcohol consumption in a general population: results of the Study of Health in Pomerania (SHIP). Journal of Studies on Alcohol 200364 $75-82$.

26 Executive Summary of The Third Report of The National Cholesterol Education Program (NCEP). Expert panel on detection, evaluation, and treatment of high blood cholesterol in adults (Adult Treatment Panel III). Journal of the American Medical Association $20012852486-2497$.

27 Volzke H, Robinson DM, Kleine V, Deutscher R, Hoffmann W, Ludemann J, Schminke U, Kessler C \& John U. Hepatic steatosis is associated with an increased risk of carotid atherosclerosis. World Journal of Gastroenterology 200511 1848-1853.

28 Völzke H, Schwarz S, Baumeister SE, Wallaschofski H, Schwahn C, Grabe HJ, Kohlmann T, John U \& Dören M. Menopausal status and hepatic steatosis in a general female population. Gut $2007 \mathbf{5 6}$ 594-595.

29 Baumeister SE, Volzke H, Marschall P, John U, Schmidt CO, Flessa S \& Alte D. Impact of fatty liver disease on health care utilization and costs in a general population: a 5-year observation. Gastroenterology 2008134 85-94.

30 Picardi A, Gentilucci UV, Zardi EM, Caccavo D, Petitti T, Manfrini S, Pozzilli P \& Afeltra A. TNF-alpha and growth hormone resistance in patients with chronic liver disease. Journal of Interferon $\mathcal{E}$ Cytokine Research 200323 229-235.

31 Takahashi Y, Iida K, Takahashi K, Yoshioka S, Fukuoka H, Takeno R, Imanaka M, Nishizawa $H$, Takahashi M, Seo Y, Hayashi Y, Kondo T, Okimura Y, Kaji H, Kitazawa R, Kitazawa S \& Chihara K. Growth hormone reverses nonalcoholic steatohepatitis in a patient with adult growth hormone deficiency. Gastroenterology 2007132 938-943.

32 Ichikawa T, Hamasaki K, Ishikawa H, Ejima E, Eguchi K \& Nakao K. Non-alcoholic steatohepatitis and hepatic steatosis in patients with adult onset growth hormone deficiency. Gut 2003 52914.

33 Juul A, Main K, Blum WF, Lindholm J, Ranke MB \& Skakkebaek NE. The ratio between serum levels of insulin-like growth factor (IGF)-I and the IGF binding proteins (IGFBP-1, 2 and 3) decreases with age in healthy adults and is increased in acromegalic patients. Clinical Endocrinology 199441 85-93. 
34 Blomsma MC, de Knegt RJ, Dullaart RP \& Jansen PL. Insulin-like growth factor-I in liver cirrhosis. Journal of Hepatology 199727 1133-1138.

35 Scharf J, Ramadori G, Braulke T \& Hartmann H. Synthesis of insulinlike growth factor binding proteins and of the acid-labile subunit in primary cultures of rat hepatocytes, of Kupffer cells, and in cocultures: regulation by insulin, insulinlike growth factor, and growth hormone. Hepatology 199623 818-827.

36 Paassilta M, Kervinen K, Linnaluoto M \& Kesaniemi YA. Alcohol withdrawal-induced change in lipoprotein (a): association with the growth hormone/insulin-like growth factor-I (IGF-I)/IGFbinding protein-1 (IGFBP-1) axis. Arteriosclerosis, Thrombosis, and Vascular Biology 199818 650-654.
37 Kaaks R, Bellati C, Venturelli E, Rinaldi S, Secreto G, Biessy C, Pala V, Sieri S \& Berrino F. Effects of dietary intervention on IGF-I and IGF-binding proteins, and related alterations in sex steroid metabolism: the diet and androgens (DIANA) randomised trial. European Journal of Clinical Nutrition 200357 1079-1088.

38 Romeo S, Kozlitina J, Xing C, Pertsemlidis A, Cox D, Pennacchio LA, Boerwinkle E, Cohen JC \& Hobbs HH. Genetic variation in PNPLA3 confers susceptibility to nonalcoholic fatty liver disease. Nature Genetics 200840 1461-1465.

Received 14 July 2009

Accepted 28 July 2009 